\title{
Induction of somatic embryogenesis in soybean: physicochemical factors influencing the development of somatic embryos
}

\author{
Gisele Aparecida Bonacin ${ }^{1}$, Antonio Orlando Di Mauro ${ }^{2}$, Roberto Carlos de Oliveira ${ }^{1}$ and Dilermando Perecin ${ }^{2}$
}

\begin{abstract}
The embryogenic capability of five soybean cultivars (Renascença, IAS-5, IAC-17, BR-16 and FT-Cometa) was studied at different auxin concentrations $\left(8,10\right.$ and $12 \mathrm{mg} / \mathrm{l}$ naphthalene acetic acid, NAA), at different $\mathrm{pHs}(5.8$ and 7.0$)$ and at low $\left(8-12 \mu\right.$ Em $\left.{ }^{-2} \mathrm{~s}^{-1}\right)$ and high (27-33 $\left.\mu \mathrm{Em}^{-2} \mathrm{~s}^{-1}\right)$ light intensities. The experimental design was completely randomized with four replications. Immature cotyledons $4-6$ $\mathrm{mm}$ in length were placed in the six induction mediums evaluated and submitted to two light intensities. Twenty immature cotyledons per cultivar were placed on each Petri dish, which was considered to be one replication. The number of somatic embryos per treatment per replication was counted. The results showed genotype influence on somatic embryogenic capability of each cultivar, with the most embryogenic cultivars being BR-16, FT-Cometa and IAS-5. Auxin concentration and $\mathrm{pH}$ value also influenced somatic embryo production, with $10 \mathrm{mg} / \mathrm{l} \mathrm{NAA}$ being the best auxin concentration and 7.0 the best $\mathrm{pH}$ value. The interactions cultivar $\mathrm{x}$ auxin, auxin $\mathrm{x} \mathrm{pH}$ and $\mathrm{pH} \mathrm{x}$ light were significant, while other double interactions were not. All triple and quadruple interactions were significant, except cultivar x pH x light. No significant differences in somatic embryo production were observed in medium with different pHs or when the Petri dishes containing immature cotyledons were exposed to the two light intensities evaluated. However, a higher number of somatic embryos was produced when the medium $\mathrm{pH}$ was adjusted to 7.0.
\end{abstract}

\section{INTRODUCTION}

Soybean [Glycine max (L.) Merril], one of the most important cultivated species, is outstanding as a source of vegetable oil and protein. Most by-products of soybean oil extraction are used in animal nutrition. Furthermore, the chemical composition of soybean seeds recommends it as one of the main solutions for global food deficits. Thus, the soybean has been the object of intense genetic improvement programs that have resulted in the development of new cultivars adapted to Brazilian climatic conditions.

As a consequence of the continuously growing global demand for food and protein, new commercial cultivars, with greater capacity to withstand environmental stresses and genetically improved to increase yield quantity and quality are desirable. Tissue culture and plant transformation techniques open new possibilities for improving soybeans (Hildebrand et al., 1991), and among them methods of in vitro regeneration and somatic embryogenesis stand out.

Considering the importance of both the identification of cultivars suitable for embryogenic propagation and the knowledge of the interaction between cultivars and inherent physicochemical factors involved in the induction of somatic embryogenesis, the aim of the present research was to evaluate the behavior of soybean cultivars in relation to embryogenic capacity at different auxin concentrations (naphthalene acetic acid, NAA), pH values, and light intensities, as well as to determine interactions between these factors.

\section{MATERIAL AND METHODS}

\section{Soybean cultivars and treatments}

The soybean cultivars IAS-5, IAC-17, Renascença, BR-16 and FT-Cometa were used as source of explants, and maintained in the greenhouse at a 14-h photoperiod and a temperature of approximately $30^{\circ} \mathrm{C}$. Pods containing immature 4-6-mm long cotyledons were collected, transported to the laboratory and submitted to asepsis (Mauro et al., 1994). In a laminar flow hood, pods were excized and immature cotyledons extracted and placed on solid MS media (Murashige and Skoog, 1962) containing different auxin (NAA) concentrations $(8,10$ and $12 \mathrm{mg} / \mathrm{l})$. Two $\mathrm{pH}$ values of the media were also evaluated (5.8 and 7.0). Twenty cotyledons of each cultivar were placed on each Petri dish (100 $\mathrm{mm}$ in diameter), sealed with Parafilm, and incubated in a growth chamber at a 23 -h photoperiod and approximately $26^{\circ} \mathrm{C}$. Petri dishes containing the immature cotyledons were exposed to different light intensities $\left(8-12 \mu \mathrm{Em}^{-2} \mathrm{~s}^{-1}\right.$ (low) and $27-33 \mu \mathrm{Em}^{-2} \mathrm{~s}^{-1}$ (high)), since great attention has recently been given to light intensity in the growth chamber.

\section{Experimental design and statistical analysis}

The experimental design was an entirely randomized factorial model $(5 \times 3 \times 2 \times 2 \times 4)$. The five soybean cultivars were combined with three auxin concentrations, two

${ }^{1}$ Estudante de graduação, UNESP, Campus de Jaboticabal, 14870-000 Jaboticabal, SP, Brasil. 
$\mathrm{pH}$ values, two light intensity levels, and four replications. The induction period was 90 days and cotyledons were transferred to fresh media at 15-day intervals. As somatic embryos appeared they were removed and counted. The suggestions of Snedecor and Cochran (1989) were followed for statistical analysis. The number of somatic embryos per treatment was transformed to the scale $\sqrt{x+0.5}$ for data normalization (Banzato and Kronka, 1992).

\section{RESULTS AND DISCUSSION}

Table I shows significant differences $(\mathrm{P}<0.01)$ in somatic embryo production between cultivars and also that auxin level had an important influence. The influence of cultivar genotype on somatic embryo formation was also reported by Parrot et al. (1989) and Komatsuda and Ko (1990). Significant differences were also observed in auxin levels $(\mathrm{P}<0.01)$ and $\mathrm{pH}(\mathrm{P}<0.05)$, indicating that the production of somatic embryos was independently influenced by these two factors. The two light intensities had no effect on somatic embryo production. The double interactions were significant for cultivar $\mathrm{x}$ auxin $(\mathrm{P}<0.01)$, auxin $\mathrm{x} \mathrm{pH}$ and $\mathrm{pH} \mathrm{x}$ light $(\mathrm{P}<0.05)$. Triple and quadruple interactions were all significant $(\mathrm{P}<0.01)$, except for cultivar $\mathrm{x}$ $\mathrm{pH} \times$ light. These results show that each factor is influenced by the other. Coefficient of variation was $18.04 \%$, suggesting reliable results.

Analysis of variance applied to axin levels x cultivars and cultivar $x$ auxin levels (Table II) showed that different auxin concentrations had important effects $(\mathrm{P}<0.01)$ on the somatic embryo formation of each cultivar. Similarly, the same Table shows that each cultivar produced a different number of somatic embryos at each auxin concentration $(\mathrm{P}<0.01)$. Considering auxin levels within $\mathrm{pH}$ values, the results showed that auxin had significant effects $(\mathrm{P}<0.01)$ on somatic embryo production at each medium $\mathrm{pH}$. On the other hand, the same Table also shows that the evaluated medium pHs only had significant effects $(\mathrm{P}<0.01)$ when $12 \mathrm{mg} / \mathrm{l}$ NAA was added to the induction medium. Regarding light intensities within $\mathrm{pH}$ values and $\mathrm{pH}$ values within light intensities, although Tables I and II showed some interaction between these factors, no differences among means of somatic embryo production at the two light intensities and $\mathrm{pH}$ values were observed by the Tukey test (Table III). This may indicate that further studies with an increased range and number of light intensities are necessary.

Table IV shows the mean number of somatic embryos obtained from cotyledons of the five soybean cultivars induced at three different auxin concentrations. Each cultivar produced a significantly higher number $(\mathrm{P}<0.05)$ of somatic embryos when the MS media were supplemented with $10 \mathrm{mg} / \mathrm{l} \mathrm{NAA}$. Interestingly, in most research on somatic embryogenesis in the soybean this was the concentration used and the reason why modified MS medium was termed N10 (Lazzeri et al., 1985; Hartweck et al., 1988;
Table I - Variance analysis results of number of somatic embryos in an entirely randomized factorial model.

\begin{tabular}{|c|c|c|}
\hline Source of variation & d.f. & Mean square \\
\hline Cultivar & 4 & $12.02 * *$ \\
\hline Auxin & 2 & $21.89 * *$ \\
\hline $\mathrm{pH}$ & 1 & $0.93 *$ \\
\hline Light & 1 & $0.48^{\mathrm{NS}}$ \\
\hline Cultivar $\mathrm{x}$ auxin & 8 & $0.96 * *$ \\
\hline Cultivar x pH & 4 & $0.31^{\mathrm{NS}}$ \\
\hline Cultivar $\mathrm{x}$ light & 4 & $0.35^{\mathrm{NS}}$ \\
\hline Auxin $\times \mathrm{pH}$ & 2 & $0.78^{*}$ \\
\hline Auxin $x$ light & 2 & $0.17^{\mathrm{NS}}$ \\
\hline $\mathrm{pH} \times$ light & 1 & $1.14 *$ \\
\hline Cultivar $\mathrm{x}$ auxin $\mathrm{x} \mathrm{pH}$ & 8 & $1.49 * *$ \\
\hline Cultivar $\mathrm{x}$ auxin $\mathrm{x}$ light & 8 & $1.85^{* *}$ \\
\hline Cultivar x pH x light & 4 & $0.34^{\mathrm{NS}}$ \\
\hline Auxin $\times \mathrm{pH} \times$ light & 2 & $2.07 * *$ \\
\hline Cultivar $\mathrm{x}$ auxin $\mathrm{x}$ pH $\mathrm{x}$ light & 8 & $1.29 * *$ \\
\hline Error & 180 & 0.20 \\
\hline $\begin{array}{l}\text { CV\% }=18.04 \\
\text { Mean }=2.52\end{array}$ & & \\
\hline
\end{tabular}

**Significant at $1 \%$ level of probability $(\mathrm{P}<0.01)$. *Significant at $5 \%$ level

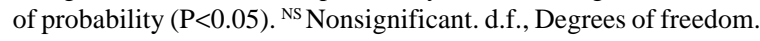

Table II - Analysis of variance for the partition of degrees of freedom (d.f.) in auxin levels x cultivars, cultivars $\mathrm{x}$ auxin levels, $\mathrm{pH}$ values $\mathrm{x}$ auxin levels, auxin levels $\mathrm{x} \mathrm{pH}$ value, light intensities $\mathrm{x} \mathrm{pH}$ values and $\mathrm{pH}$ values $\mathrm{x}$ light intensities.

\begin{tabular}{|lcc|}
\hline Source of variation & d.f. & Mean square \\
\hline Auxin x Renascença & 2 & $5.72^{* *}$ \\
Auxin x IAS-5 & 2 & $2.14^{* *}$ \\
Auxin x IAC-17 & 2 & $6.30^{* *}$ \\
Auxin x BR-16 & 2 & $1.48^{* *}$ \\
Auxin x FT-Cometa & 2 & $10.10^{* *}$ \\
Cultivar x 8 mg/l NAA & 4 & $6.34^{* *}$ \\
Cultivar x 10 mg/l NAA & 4 & $3.10^{* * *}$ \\
Cultivar x 12 mg/l NAA & 4 & $4.50^{* *}$ \\
Auxin x pH 5.8 & 2 & $8.00^{* *}$ \\
Auxin x pH 7.0 & 2 & $14.67^{* *}$ \\
pH x 8 mg/l auxin & 2 & $0.17^{\mathrm{NS}}$ \\
pH x 10 mg/l auxin & 2 & $0.06^{\mathrm{NS}}$ \\
pH x 12 mg/l auxin & 2 & $2.26^{* *}$ \\
Light x pH 5.8 & 2 & $0.07^{\mathrm{NS}}$ \\
Light x pH 7.0 & 2 & $1.55^{* *}$ \\
pH x 8-12 $\mu \mathrm{Em}^{-2} \mathrm{~s}^{-1}$ light & 2 & $2.06^{* *}$ \\
pH x 27-33 $\mu \mathrm{Em}^{-2} \mathrm{~s}^{-1}$ light & 2 & $0.01^{\mathrm{NS}}$ \\
\hline
\end{tabular}

**Significant at $1 \%$ level of probability $(\mathrm{P}<0.01)$. ${ }^{\text {NS }}$ Nonsignificant.

Table III - Means of somatic embryos (NE) obtained from cotyledons induced at two $\mathrm{pH}$ values and at two ligtht intensities.

\begin{tabular}{|ccc|}
\hline $\mathrm{pHs}$ & \multicolumn{2}{c|}{ Light intensities/means*(NE) } \\
\cline { 2 - 3 } & $8-12 \mu \mathrm{Em}^{-2} \mathrm{~s}^{-1}$ & $27-33 \mu \mathrm{Em}^{-2} \mathrm{~s}^{-1}$ \\
\hline 5.8 & $2.56 \mathrm{a} \mathrm{A}$ & $2.52 \mathrm{a} \mathrm{A}$ \\
7.0 & $2.31 \mathrm{a} \mathrm{A}$ & $2.53 \mathrm{a} \mathrm{A}$ \\
\hline
\end{tabular}

* Means followed by the same lower case letters in the column and by the same upper case letters in the line did not differ at $5 \%$ level of probability by the Tukey test. 
Parrot et al., 1988, 1989; Komatsuda et al., 1991; Dahmer et al., 1991; Mauro et al., 1994, 1995a; Nóbrega, 1996).

Considering the best auxin concentration $(10 \mathrm{mg} / \mathrm{l}$ NAA) and the behavior of each cultivar within auxin concentrations (Table IV), cultivar influence on embryo formation can be seen, confirming the results obtained by Komatsuda and Okyama (1988), Parrot et al. (1989), Calvo (1989), Komatsuda et al. (1992), Mauro et al. (1995b) and Nóbrega (1996). Thus, cultivars IAS-5, FT-Cometa and BR16 were the most embryogenic, as also observed by Ferreira et al. (1990), Bodanese-Zanetini et al. (1993) and Droste et al. (1993).

Comparisons among means for somatic embryo production at three auxin levels and two $\mathrm{pH}$ values (Table V) confirmed that the best auxin concentration for inducing somatic embryo formation is $10 \mathrm{mg} / \mathrm{l} \mathrm{NAA}$. No differences were observed in somatic embryo production between the two $\mathrm{pH}$ values when 8 or $10 \mathrm{mg} / \mathrm{l} \mathrm{NAA}$ was added to the induction medium; however, a higher mean number of somatic embryos was obtained when the medium $\mathrm{pH}$ was adjusted to 7.0. This result disagrees with Pierik (1989), who emphasized that a $\mathrm{pH}$ in the 5.0 to 6.5 range is suitable for somatic embryo development, and may explain why most of the recent papers have used $\mathrm{pH}=7.0$ in the induction medium.

Regression in the number of somatic embryos produced by each cultivar as a function of the three auxin concentrations is shown in Figure 1. The results demonstrate an increasing response to auxin concentration up to $10 \mathrm{mg} / \mathrm{l}$ NAA. Greater concentrations decreased somatic embryo formation. The largest determination coefficient $\left(\mathrm{R}^{2}\right)$ was obtained for IAC-17 $\left(\mathrm{R}^{2}=0.90\right)$ and the smallest value for IAS-5 $\left(R^{2}=0.20\right)$. The $R^{2}$ value obtained for cultivar IAS-5 may be due to a variation in embryo production related to auxin concentration, and may be possibly associated with some endogenous or physiological factor in the cultivar.

Table IV - Means of somatic embryos (NE) obtained from cotyledons of the five soybean cultivars induced at three different auxin concentrations.

\begin{tabular}{|llll|}
\hline Cultivars & \multicolumn{3}{c|}{ Auxin concentrations (NAA)/means*(NE) } \\
\cline { 2 - 4 } & $8 \mathrm{mg} / 1$ & $10 \mathrm{mg} / 1$ & $12 \mathrm{mg} / 1$ \\
\hline Renascença & $1.64 \mathrm{~b} \mathrm{~B}$ & $2.78 \mathrm{bc} \mathrm{A}$ & $1.90 \mathrm{bc} \mathrm{B}$ \\
IAS-5 & $2.68 \mathrm{a} \mathrm{B}$ & $3.33 \mathrm{a} \mathrm{A}$ & $2.71 \mathrm{a} \mathrm{B}$ \\
IAC-17 & $1.38 \mathrm{~b} \mathrm{~B}$ & $2.51 \mathrm{c} \mathrm{A}$ & $1.48 \mathrm{c} \mathrm{B}$ \\
BR-16 & $2.61 \mathrm{a} \mathrm{B}$ & $3.17 \mathrm{ab} \mathrm{A}$ & $2.68 \mathrm{a} \mathrm{B}$ \\
FT-Cometa & $2.64 \mathrm{a} \mathrm{B}$ & $3.62 \mathrm{a} \mathrm{A}$ & $2.05 \mathrm{~b} \mathrm{C}$ \\
\hline Mean & $2.19 \mathrm{~b}$ & $3.09 \mathrm{a}$ & $2.17 \mathrm{~b}$ \\
\hline
\end{tabular}

* Means followed by the same lower case letters in the column and by the same upper case letters in the line did not differ at $5 \%$ level of probability by the Tukey test.

Table V - Means of somatic embryos (NE) obtained from cotyledons induced at two $\mathrm{pH}$ values and at three different auxin concentrations.

\begin{tabular}{|cccc|}
\hline \multirow{2}{*}{$\mathrm{pHs}$} & \multicolumn{3}{c|}{ Auxin concentrations (NAA)/means*(NE) } \\
\cline { 2 - 4 } & $8 \mathrm{mg} / \mathrm{l}$ & $10 \mathrm{mg} / \mathrm{l}$ & $12 \mathrm{mg} / \mathrm{l}$ \\
\hline 5.8 & $2.24 \mathrm{a} \mathrm{B}$ & $3.05 \mathrm{a} \mathrm{A}$ & $2.33 \mathrm{a} \mathrm{B}$ \\
7.0 & $2.15 \mathrm{a} \mathrm{B}$ & $3.11 \mathrm{a} \mathrm{A}$ & $2.00 \mathrm{~b} \mathrm{~B}$ \\
\hline
\end{tabular}

* Means followed by the same lower case letters in the column and by the same upper case letters in the line did not differ at 5\% level of probability by the Tukey test.

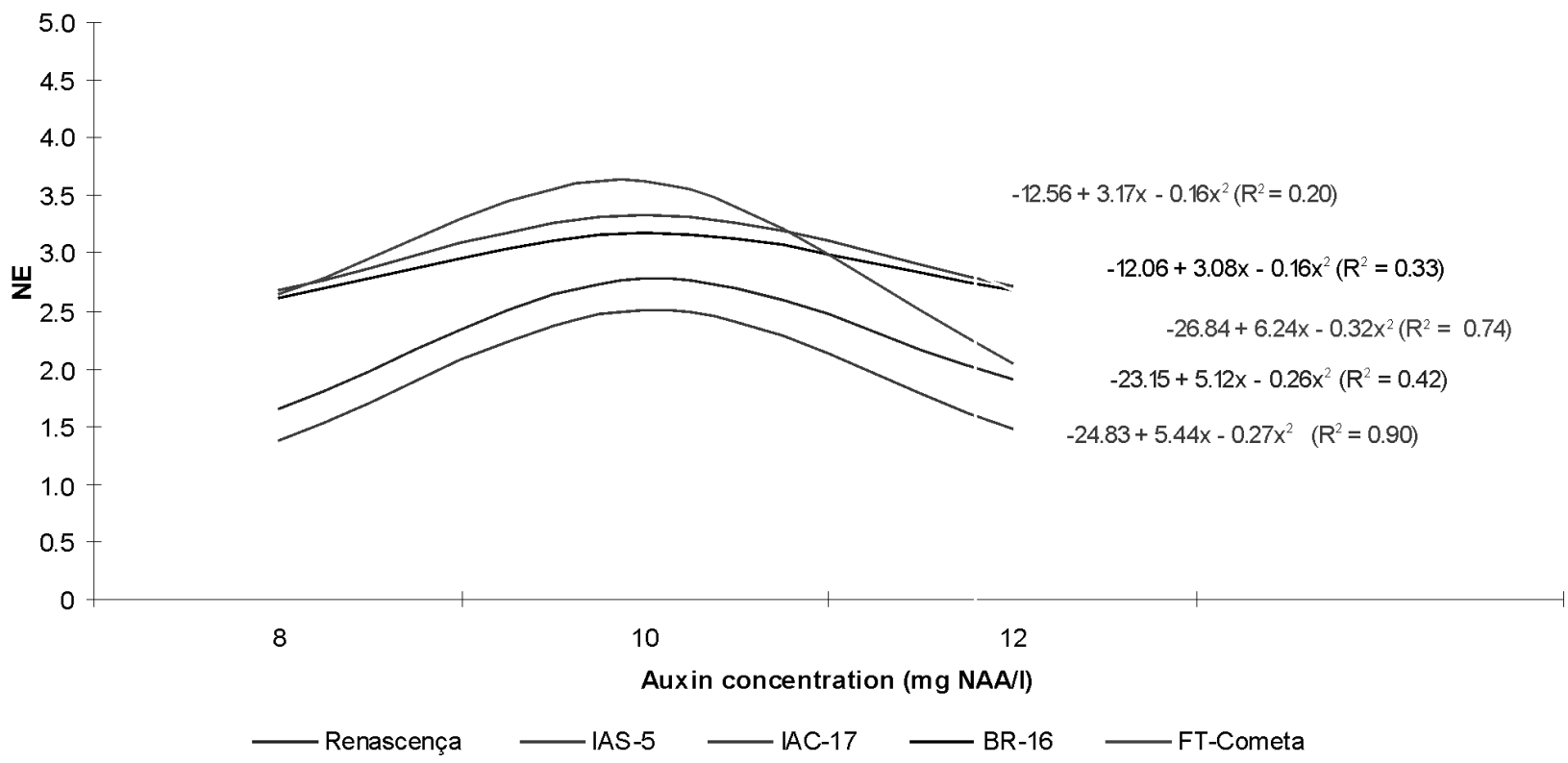

Figure 1 - Regression of the number of somatic embryos (NE) produced by each cultivar as a function of the three auxin concentrations. 


\section{ACKNOWLEDGMENTS}

Publication supported by FAPESP.

\section{RESUMO}

A capacidade embriogênica de cinco cultivares de soja (Renascença, IAS-5, IAC-17, BR-16 e FT-Cometa) foi estudada em diferentes concentrações de auxina ( 8,10 e 12 mg/l de NAA), em diferentes valores de pHs $(5,8$ e 7,0$)$ e em baixa $\left(8-12 \mu \mathrm{Em}^{-2}\right.$ $\left.\mathrm{s}^{-1}\right)$ e em alta $\left(27-33 \mu \mathrm{Em}^{-2} \mathrm{~s}^{-1}\right)$ intensidade luminosa. O delineamento experimental foi o inteiramente casualizado com quatro repetições. Cotilédones imaturos com 4-6 mm de tamanho foram depositados nos seis meios indutivos e submetidos às duas intensidades luminosas. Vinte cotilédones imaturos de cada cultivar foram depositados em cada placa de Petri, que foi considerada como uma repetição. O número de embriões somáticos por tratamento, por repetição foi contado e os resultados evidenciaram a influência do genótipo na capacidade embriogênica de cada cultivar, revelando-se mais embriogênicos os cultivares FT-Cometa, IAS-5 e BR-16. A concentração de auxina e o valor do $\mathrm{pH}$ tiveram influência no número de embriões somáticos produzidos, sendo $10 \mathrm{mg} / \mathrm{l}$ de NAA a melhor concentração de auxina e 7,0 o melhor valor de $\mathrm{pH}$. As interações cultivar $\mathrm{x}$ auxina, auxina $\mathrm{x} \mathrm{pH}$ e $\mathrm{pH} \mathrm{x}$ luz revelaram-se significativas, e as demais duplas interações foram não significativas. Todas as interações triplas e quádruplas foram significativas, exceto cultivar x pH x luz. Não foram observadas diferenças significativas na produção de embriões somáticos nos meios com diferentes pHs e nem quando as placas de Petri contendo os cotilédones imaturos foram submetidas às duas intensidades luminosas avaliadas, porém maior número de embriões somáticos foi produzido quando o $\mathrm{pH}$ do meio foi ajustado para 7,0.

\section{REFERENCES}

Banzato, D.A. and Kronka, S.N. (1992). Experimentação Agrícola. FUNEP, Jaboticabal.

Bodanese-Zanetini, M.H., Ortolan, M.G.S. and Hu, C. (1993). Somatic embryoid induction from Brazilian soybean cultivars. Rev. Bras. Genet. 16: $129-134$.

Calvo, E.S. (1989). Embriogênese somática em soja (Glycine max (L.) Merrill). Master's thesis, Escola Superior de Agricultura "Luiz de Queiroz", Universidade de São Paulo, Piracicaba.

Dahmer, M.L., Collins, G.B. and Hildebrand, D.F. (1991). Lipid content and composition of soybean somatic embryos. Crop Sci. 31: 741-746.

Droste, A., Bodanese-Zanettini, M.H. and Hu, C. (1993). Meristem culture of Brazilian soybean cultivars. Rev. Bras. Genet. 16: 135-144.

Ferreira, A.G., Ching, Y.H. and Santarem, E.R. (1990). Somatic embryo- genesis of soybean (Glycine max L.) Merrill) Brazilian cultivars Ivorá and IAS-5. Phyton 51: 139-144.

Hartweck, L.M., Lazzeri, D.A., Cui, D., Collins, G.B. and Williams, E.G. (1988). Auxin-orientation effects on somatic embryogenesis from immature soybean cotyledons. In vitro Cell. Dev. Biol. 24: 821-828.

Hildebrand, D.F., Liu, W., Deng, W., Grayburn, W.S. and Collins, G.B. (1991). Progress in biotechnological approaches in the improvement of seed quality. In: Plant Biotechnology and the Oil and Fats Industry (Rattra, J.B.M., ed.). University Press and American Oil Society Press, Lexington, p. 13.

Komatsuda, T. and Ko, S.W. (1990). Screening of soybean (Glycine max (L.) Merrill) genotypes for somatic embryo production from immature embryo. Jpn. J. Breed. 40: 249-251.

Komatsuda, T. and Okyama, K. (1988). Genotypes of high competence for somatic embryogenesis and plant regeneration in soybean Glycine max. Theor. App. Genet. 75: 695-700.

Komatsuda, T., Kaneko, K. and Oka, S. (1991). Genotype x sucrose interactions for somatic embryogenesis in soybean. Crop Sci. 31: 333337.

Komatsuda,T., Lee, W. and Oka, S. (1992). Maturation and germination of somatic embryos as affected by sucrose and plant growth regulators in soybeans Glycine gracilis Skvortz and Glycine max (L.) Merril. Plant Cell Tissue Organ Cult. 28: 103-113.

Lazzeri, P.A., Hildebrand, D.F. and Collins, G.B. (1985). A procedure for plant regeneration from immature cotyledons tissue of soybean. Plant Mol. Biol. Rep. 3: 160-167.

Mauro, A.O., Pfeiffer, T., Collins, G.B. and Vieira, R.D. (1994). Estudo da interação entre genótipos e posições de explantes de soja (Glycine $\max (\mathrm{L})$ Merril) no meio de cultura para indução da embriogênese somática. Científica 22: 133-144.

Mauro, A.O., Pfeiffer, T. and Collins, G.B. (1995a). Inheritance of soybean susceptibility to Agrobacterium tumefaciens and its relationship to transformation. Crop Sci. 35: 1152-1156.

Mauro, A.O., Nóbrega, J.C. and Collins, G.B. (1995b). Screening soybean genotypes regarding to their ability to produce somatic embryos. Científica 23: 218-223.

Murashige, T. and Skoog, F. (1962). A revised medium for rapid growth and biossays with tobacco tissue cultures. Physiol. Plant. 15: 473-477.

Nóbrega, J.C. (1996). Seleção de genótipos brasileiros de soja para embriogênese somática e suscetibilidade à Agrobacterium tumefaciens. Master's thesis, Faculdade de Ciências Agrárias e Verterinárias, Universidade Estadual Paulista, Jaboticabal.

Parrot, W.A., Dryden, G., Vogt, S., Hildebrand, D.F., Collins, G.B. and Williams, E.G. (1988). Optimization of somatic embryogenesis and embryo germination in soybean in vitro. In Vitro Cell Dev. Biol. 24: 817-820.

Parrot, W.A., William, E.G., Hildebrand, D.F. and Collins, G.B. (1989). Effect of genotype on somatic embryogenesis from immature cotyledons of soybean. In vitro Cell Tissue Organ Cult. 16: 15-21.

Pierik, R.L.M. (1989). In Vitro Culture of Higher Plants. Martinus Nijhoff Publishers, Dordrecht.

Snedecor, G.W. and Cochran, W.G. (1989). Statistical Methods. Iowa State University, Ames.

(Received March 2, 2000) 